\title{
ANALISIS PENGUASAAN KONSEP DAN MISKONSEPSI BIOLOGI DENGAN TEKNIK MODIFIKASI CERTAINTY OF RESPONSE INDEX PADA SISWA SMP SE-KOTA SUMBAWA BESAR
}

\author{
Maesyarah $^{1)}$, A.Wahab Jufri. ${ }^{2),}$ Kusmiyati $^{2)}$ \\ ${ }^{1)}$ Mahasiswa Program Studi P.Biologi FKIP Universitas Mataram \\ ${ }^{2)}$ Staf Pengajar Program Studi P.Biologi FKIP Universitas Mataram \\ Email: maesyarah@gmail.com
}

\begin{abstract}
Abstrak: Salah satu tujuan pembelajaran IPA di SMP/Mts adalah meningkatkan pengetahuan, konsep, dan keterampilan IPA. Penelitian ini bertujuan untuk menganalisis penguasaan konsep dan miskonsepsi biologi pada siswa SMP Se-Kota Sumbawa Besar. Jenis penelitian ini adalah penelitian deskriptif. Populasi dalam penelitian ini yaitu seluruh siswa kelas VIII SMP Negeri Se-Kota Sumbawa Besar tahun ajaran 2013/2014. Sampel penelitian dipilih berdasarkan lokasi sekolah yaitu SMP pusat kota, SMP di pinggiran kota, dan SMP di luar yang ditentukan dengan teknik Cluster Random Sampling. Instrumen penelitian berupa pengembangan tes pilihan ganda dengan teknik modifikasi Certainty of Response Index. Hasil penelitian yaitu (1) penguasaan konsep biologi pada siswa SMP di pusat kota tergolong tinggi, penguasaan konsep biologi pada siswa SMP di pinggiran kota tergolong sedang, dan penguasaan konsep biologi pada siswa SMP di luar kota tergolong rendah;(2) miskonsepsi yang terjadi pada siswa SMP di pusat Kota, SMP di pinggiran kota, dan SMP di luar kota termasuk dalam kategori sedang; (3) miskonsepsi materi ciri-ciri makhluk hidup tergolong tinggi,, miskonsepsi materi keanekaragaman makhluk hidup tergolong sedang dan miskonsepsi materi tingkat organisasi kehidupan tergolong sedang; (4) retensi penguasaan konsep selama dua minggu pada SMP di pusat kota meningkat sebesar 5,70\%, retensi penguasaan konsep siswa pada SMP di pinggiran kota meningkat sebesar 11,69\%, dan retensi penguasaan konsep siswa pada SMP di luar kota meningkat sebesar 5,75\%. Perbedaan tingkat penguasaan konsep biologi dari ketiga kelompok sampel kemungkinan disebabkan karena perbedaan minat belajar siswa. Salah satu penyebab terjadinya miskonsepsi biologi pada siswa SMP se-kota Sumbawa Besar adalah kurangnya kemampuan dalam mengolah informasi dan rendahnya tingkat penalaran. Miskonsepsi pada materi ciri-ciri mahluk hidup tergolong tinggi disebabkan siswa hanya mampu menyebutkan dan memberi contoh, tanpa mampu menjelaskan konsep ciri-ciri makhluk hidup. Perbedaan retensi penguasaan konsep siswa pada ketiga kelompok sampel dapat dipengaruhi oleh faktor kelupaan pada siswa. Retensi dapat ditingkatkan dengan penggunaan strategi pembelajaran aktif dan pembelajaran bermakna.
\end{abstract}

Kata kunci: penguasaan konsep, miskonsepsi, teknik modifikasi CRI

\begin{abstract}
One of the objectives science in secondary school is to improve the student's knowledge, attainment concept, and process skills science. This descriptive research is aimed to analyze the understanding concept and misconception of Biology in the Junior high school's students at Sumbawa Besar City. The kind of this research is descriptive. The population consist of 1197 students of eight grade in six Junior High School at Sumbawa Besar City in academic year of 2013/2014. The sample of this research was selected based on school location consist of junior high school in central town, suburban, and rural area of Sumbawa Besar City which were determined by Cluster Random Sampling. The research's instrument is developing multiple-choice test with modification technique of CRI. The results of this research shows : (1) understanding concepts of biology in junior high schools' students in central town is classified as high, while that students in suburban is classified as moderate, and students in rural area of Sumbawa Besar City is classified as low; (2) misconceptions that occur in material about characteristic of living thing, diversity of living thing, and levels of live organization at junior high schools' students in central town, suburban and rural area of Sumbawa Besar City are classified as moderate; (3) misconceptions occur in characteristic of living things material classified as high, misconceptions occur in of living things materials and levels of life organization are classified as moderate; (4) retentions of understanding concept during two weeks of the junior high school's student in central town is increase by $5.50 \%$,while that of student in suburban is increase by $11.38 \%$, and student in rural area of Sumbawa Besar City is increase by $5.55 \%$. Difference in the level of attainment concepts of the three sample groups is probably due to difference interest in learning of student. One of the causes of biological misconceptions on junior high school students at Sumbawa Besar city is the lack of ability to process information and low level of reasoning. Misconceptions on the material characteristics of living thing is high because students were only able to mention and give examples, without being able to explain the concept of the characteristics of living thing. Differences in students' attainment concepts retention in 1 three groups of samples can be affected by factors on student forgetfulness. Retention can be enhanced with the use of active learning strategies and meaningful learning.
\end{abstract}

\section{Keywords : understanding concepts, misconceptions, technique of modified CRI}

\section{PENDAHULUAN}

Salah satu tujuan pembelajaran IPA di SMP/Mts adalah meningkatkan pengetahuan, konsep, dan keterampilan IPA [1]. Penelitian Gonzales [2] menunjukkan rata-rata hasil belajar IPA pada ranah kognitif siswa SMP di Indonesia termasuk dalam kategori rendah. Hal tersebut menunjukkan tingkat penguasaan konsep IPA siswa SMP di Indonesia masih cukup rendah. Penguasaan konsep merupakan kemampuan seseorang untuk mengerti apa yang 
diajarkan, menangkap makna apa yang dipelajari, memanfaatkan isi bahan yang dipelajari, serta memecahkan masalah yang berhubungan dengan materi yang dipelajari [3. Rendahnya penguasaan konsep siswa dapat disebabkan oleh kesulitan belajar biologi [4] dan terjadinya miskonsepsi. Miskonsepsi adalah pemahaman yang berbeda yang tidak sesuai dengan penjelasan ilmiah [5]. Miskonsepsi dapat menghambat pemahaman yang bermakna dan kinerja yang baik dalam pelajaran serta merupakan salah satu sumber kesulitan belajar. [6-8].

Setyadi [9] menyatakan bahwa salah satu faktor yang menyebabkan tingkat penguasaan rendah dan tingkat miskonsepsi masuk dalam kriteria tinggi karena dalam benak siswa sudah terdapat konsep yang didasarkan pada pengetahuan sebelumnya. Hal ini sejalan dengan pendapat Carey [10] yang menyatakan untuk dapat menguasai konsep, siswa harus dapat menghubungkan materi yang telah dibaca dari buku teks atau yang didengar dari penjelasan guru dengan pengetahuan yang telah diketahui sebelumnya.

Hermawati [11] mengungkapkan bahwa pengetahuan yang diperoleh dengan menerima, mengingat dan menghafal tidak akan tertanam lama dalam ingatan siswa, sehingga berakibat pada kurangnya kemampuan siswa dalam memahami pelajaran. Hal tersebut berkaitan dengan retensi yang merupakan komponen belajar [12] Retensi adalah apa yang tertinggal dan dapat diingat kembali setelah seseorang mempelajari sesuatu. Dengan retensi, membuat apa yang dipelajari seseorang tertinggal lebih lama dalam struktur kognitif dan dapat diingat kembali apabila diperlukan [13].

Menurut Shi [14], penggunaan tes pilihan ganda dirancang untuk mengevaluasi pemahaman konseptual dan mendiagnosis kesulitan dalam disiplin ilmu tertentu telah berkembang secara signifikan dalam beberapa tahun terakhir. Hasan [15] mengembangkan suatu teknik identifikasi yang dikenal dengan istilah Certainty of Response Index (CRI) yang merupakan teknik dengan pengukuran tingkat keyakinan/kepastian responden dalam menjawab setiap pertanyaan yang diberikan.

Hakim [16] mengembangkan teknik $C R I$ menjadi teknik modifikasi CRI. Teknik modifikasi CRI merupakan teknik untuk menganalisis penguasaan konsep dan miskonsepsi yang disesuikan dengan karakter dari siswa Indonesia yang sering merasa tidak yakin dalam menjawab soal sehingga diperlukan teknik penilaian yang dapat lebih akurat dalam mengidentifikasi miskonsepsi. Teknik modifikasi CRI terdiri kombinasi soal tes pilihan ganda dengan alasan terbuka, dan indeks keyakinan siswa dalam menjawab.

Menurut data hasil ujian IPA siswa SMP se-Kota Sumbawa Besar pada tahun ajaran 2010/2011 dan tahun 2011/2012 menunjukkan adanya perbedaan ratarata daya serap siswa antara sekolah di pusat kota dengan pinggiran kota maupun luar kota [1]. Perbedaan daya serap dapat disebabkan oleh tingkat penguasaan konsep rendah dan terjadinya miskonsepsi. Berdasarkan hal tersebut perlu dilakukan penelitian tentang analisis penguasaan konsep dan miskonsepsi biologi dengan teknik modifikasi Certainty of Response Index pada siswa se-kota Sumbawa Besar.

\section{METODE PENELITIAN}

Penelitian ini dilaksanakan pada bulan Agustus sampai dengan bulan Oktober 2013 di enam SMP yang mewakili populasi siswa SMP se-kota Sumbawa Besar. Populasi yang digunakan dalam penelitian ini adalah siswa kelas VIII SMP se-Kota Sumbawa Besar. Metode pengambilan dilakukan dengan memilih sampel sekolah berdasarkan letak sekolah yaitu SMP di pusat kota, SMP di pinggiran kota, dan SMP di luar kota, dan memilih dua kelas pada masing sekolah dengan Cluster Random Sampling.

Instrumen dalam penelitian ini berupa tes dan angket. Tes diberikan dalam dua tahp dua tahap. Tes terdiri dari 29 soal yang telah diuji valid dengan uji menggunakan korelasi point biserial dan uji reabilitas dengan rumus Kuder Richardson 20.

Data penguasaan konsep diperoleh dari hasil pilihan ganda dan miskonsepsi diperoleh dengan teknik tes modifikasi CRI pada materi ciri-ciri makhluk hidup, keanekaragaman makhluk hidup, dan tingkat organisasi kehidupan dan data retensi penguasaan konsep diperoleh dari hasil tes penguasaan konsep tahap pertama dan tahap kedua. Selain itu, siswa diberikan angket diagnostik kesulitan belajar dengan tiga indikator penyebab kesulitan belajar yang berasal dari siswa, guru, dan sumber belajar.

Penerapan teknik modifikasi Certain of Response Index, prinsip-prinsip pada teknik Certainty of Response Index tetap diterapkan. Teknik CRI ditandai dengan skala tingkat keyakinan dalam menjawab soal. Skala yang digunakan adalah skala $0-5$, dengan penjabaran sebagai berikut:

Tabel 1. Skala Tingkat Keyakinan dalam Menjawab Soal berdasarkan Teknik Certainty of Response Index.

\begin{tabular}{|c|c|}
\hline Indeks & Penjelasan \\
\hline $\mathbf{0}$ & $\begin{array}{l}\text { Total guess the answer/hanya menebak ( } \\
\text { Jika menjawab soal, } 100 \% \text { ditebak) }\end{array}$ \\
\hline 1 & $\begin{array}{l}\text { Almost guess/lebih banyak menebak ( jika } \\
\text { dalam menjawab soal, persentase unsur } \\
\text { tebakan antara } 75-99 \% \text { ) }\end{array}$ \\
\hline 2 & $\begin{array}{l}\text { Not sure/tidak yakin (Jika dalam menjawab } \\
\text { soal, persentase unsur tebakan } 50-74 \% \text { ) }\end{array}$ \\
\hline 3 & $\begin{array}{l}\text { Sure/yakin (Jika dalam menjawab soal, } \\
\text { persentase unsur tebakan antara } 25-49 \%\end{array}$ \\
\hline 4 & $\begin{array}{l}\text { Almost Certain/hampir yakin tanpa } \\
\text { keraguan ( Jika dalam menjawab soal, } \\
\text { persentase unsur tebakan } 0-24 \% \text { ) }\end{array}$ \\
\hline 5 & $\begin{array}{l}\text { Certain/sangat yakin dengan tanpa } \\
\text { keraguan (Jika dalam menjawab soal tidak } \\
\text { terdapat unsur tebakan) }\end{array}$ \\
\hline
\end{tabular}

Ketentuan dalam teknik Certainty of Response Index kemudian dikembangkan oleh Hakim [16] untuk mengidentifikasi miskonsepsi yang disesuaikan dengan 
karakteristik siswa Indonesia. Dengan kata lain, kemungkinan siswa memahami konsep tetapi siswa kurang memiliki keyakinan dalam menjawab. Ketentuan terhadap kemungkinan siswa dalam menjawab soal pilihan ganda dengan alasan terbuka dengan teknik modifikasi Certainty of Reponse Index adalah sebagai berikut:

Tabel 2. Kriteria Penilaian dengan teknik Modififikasi CRI.( Hakim [16])

\begin{tabular}{|c|c|c|c|}
\hline Jawaban & Alasan & $\begin{array}{l}\text { Nilai } \\
\text { CRI }\end{array}$ & Deskripsi \\
\hline Benar & Benar & $>2,5$ & $\begin{array}{ll}\text { Menguasai } & \text { konsep } \\
\text { dengan benar } & \end{array}$ \\
\hline Benar & Benar & $<2,5$ & $\begin{array}{l}\text { Menguasai konsep tapi } \\
\text { tidak yakin }\end{array}$ \\
\hline Benar & Salah & $>2,5$ & Miskonsepsi \\
\hline Benar & Salah & $<2,5$ & $\begin{array}{l}\text { Tidak mengetahui } \\
\text { konsep }\end{array}$ \\
\hline Salah & Benar & $>2,5$ & Miskonsepsi \\
\hline Salah & Benar & $<2,5$ & $\begin{array}{l}\text { Tidak mengetahui } \\
\text { konsep }\end{array}$ \\
\hline Salah & Salah & $>2,5$ & Miskonsepsi \\
\hline Salah & Salah & $<2,5$ & $\begin{array}{l}\text { Tidak mengetahui } \\
\text { konsep }\end{array}$ \\
\hline
\end{tabular}

Data Penguasaan konsep siswa dikonversikan dalam bentuk data kualitatif sesuai dengan kriteria tingkat penguasaan konsep yaitu: 81-100 (sangat tinggi); 61-80 (tinggi); 41-60 (sedang); 21-40 (rendah); 0 - 20 (sangat rendah) [17]. Data miskonsepsi dikonversikan dalam bentuk data kualitatif sesuai dengan kriteria tingkat miskonsepsi yaitu: $81-100 \%$ (sangat tinggi); 61-80\% (tinggi); 41-60\% (sedang); 21$4 \% 0$ (rendah); $0-20 \%$ (sangat rendah) [17], sedangkan data angket diagnostik kesulitan belajar dikonversikan dalam bentuk kualifikasi faktor-faktor penyebab kesulitan belajar dengan kriteria yaitu: 81$100 \%$ (sangat lemah); 61-80\% (lemah); 41-60\% (cukup); 21-4\%0 (kuat); $0-20 \%$ (sangat kuat) [18]. Selain itu, data hasil penelitian diuji dengan analisis data kuantitatif dengan menggunakan uji anova satu jalan untuk membanding rata-rata $\mathrm{k}$ sampel, dan uji $\mathrm{t}$ untuk membandingkan rata-rata dua sampel [19]. Retensi penguasaan konsep siswa diperoleh dari hasil perbandingan tes tahap pertama dan tes tahap kedua.

\section{HASIL DAN PEMBAHASAN}

Penguasaan Konsep dan Miskonsepsi pada Materi Ciri-ciri Makhluk Hidup, Keanekaragaman Makhluk Hidup, dan Tingkat Organisasi Kehidupan.

Penguasaan konsep materi ciri-ciri makhluk hidup, keanekaragaman makhluk hidup, dan tingkat organisasi kehidupan pada siswa SMP di pusat kota (PUK) termasuk dalam kategori tinggi, penguasaan konsep siswa SMP di pinggiran kota (PIK) termasuk dalam kategori sedang, dan penguasaan konsep siswa
SMP di luar kota (LK) termasuk dalam kategori sedang. Berdasarkan hasil analisis data secara kuantitatif dengan uji $t$ menunjukkan adanya perbedaan penguasaan konsep biologi siswa dari ketiga lokasi pengambilan sampel dimana penguasaan konsep siswa SMP di pusat kota lebih tinggi daripada penguasaan konsep siswa SMP di pinggiran kota maupun luar kota, sedangkan penguasaan konsep siswa SMP di pinggiran kota lebih tinggi daripada penguasaan konsep siswa SMP diluar kota. Perbedaan penguasaan konsep biologi pada siswa di ketiga kelompok sampel kemungkinan dipengaruhi oleh minat belajar siswa. Hal ini diperkuat berdasarkan hasil penelitian Nur [20] yang menyatakan bahwa terdapat hubungan yang positif antara konsep diri dan minat belajar siswa terhadap penguasaan konsep biologi.

Miskonsepsi yang terjadi pada ketiga kelompok sampel menunjukkan persentase yang relatif sama, dengan kategori sedang dengan rentang 40-60\%. Hal ini dibuktikan berdasarkan hasil uji anova satu arah yang menunjukkan ketiga kelompok sampel baik pada tes tahap pertama maupun tes tahap kedua, menunjukkan tidak terdapat perbedaan miskonsepsi ketiga materi biologi pada siswa SMP di pusat kota, SMP di pinggiran kota, dan SMP di luar kota. Berikut adalah gambaran hasil tes miskonsepsi tahap pertama dengan teknik modifikasi CRI.

Berdasarkan hasil perhitungan miskonsepsi dari ketiga kelompok sampel pada tes tahap pertama maupun tahap kedua menunjukkan miskonsepsi pada materi ciri-ciri makhluk hidup termasuk dalam kategori tinggi sedangkan miskonsepsi pada materi keanekaragaman makhluk hidup termasuk dalam kategori sedang dan miskonsepsi pada materi tingkat organisasi kehidupan termsuk dalam kategori sedang.

Tingginya miskonsepsi pada materi ciri-ciri makhluk hidup terjadi karena siswa hanya mampu menyebutkan ciri-ciri makhluk hidup, tetapi tidak dapat menguraikan alasan yang dapat menjelaskan pengertian dari ciri-ciri tersebut yang sesuai dengan konsep.Pola jawaban siswa yan umumnya tidak dapat menguraikan alasan yang sesuai dengan konsep sehingga menyebabkan terjadinya miskonsepsi. Miskonsepsi yang terjadi pada siswa SMP se-kota Sumbawa Besar berkaitan dengan kurangnya kemampuan siswa dalam mengolah informasi dan kurangnya tingkat penalaran siswa. Hal ini didukung dengan pendapat Ma'rifah [21] yang menyatakan bahwa peserta didik yang mengabaikan informasi yang diperoleh atau menyimpannya pada memori jangka pendek tidak akan mampu menyimpan konsep secara permanen. Selain itu, tingkat penalaran yang rendah menyebabkan peserta didik tidak mampu berpikir hipotesis deduktif, proporsional, kombinatorial, dan refleksif sehingga pengetahuan tidak mampu ditangkap dengan baik. 


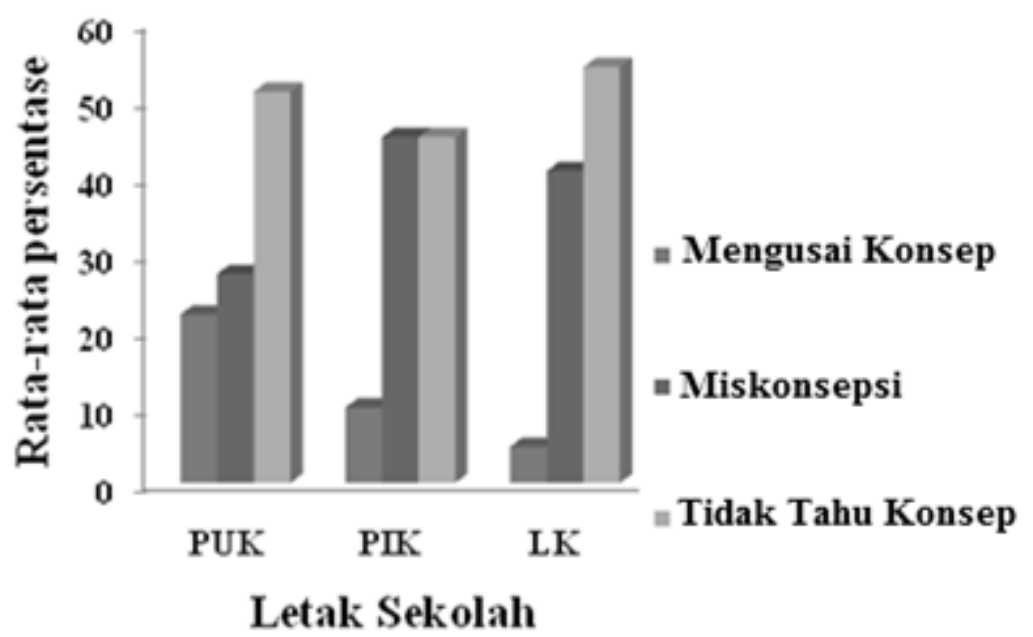

Gambar 1 Rata-rata Persentase Penguasaan Konsep, Miskonsepsi dan Tidak Tahu konsep pada Materi Ciri-ciri Makhluk Hidup, Keanekaragaman Makhluk Hidup, dan Tingkat Organisasi dan Kehidupan dengan Teknik Modifikasi Certainty of Response Index. Keterangan : PUK : SMP di pusat kota; PIK : SMP di pinggiran kota ; LK : SMP di luar kota

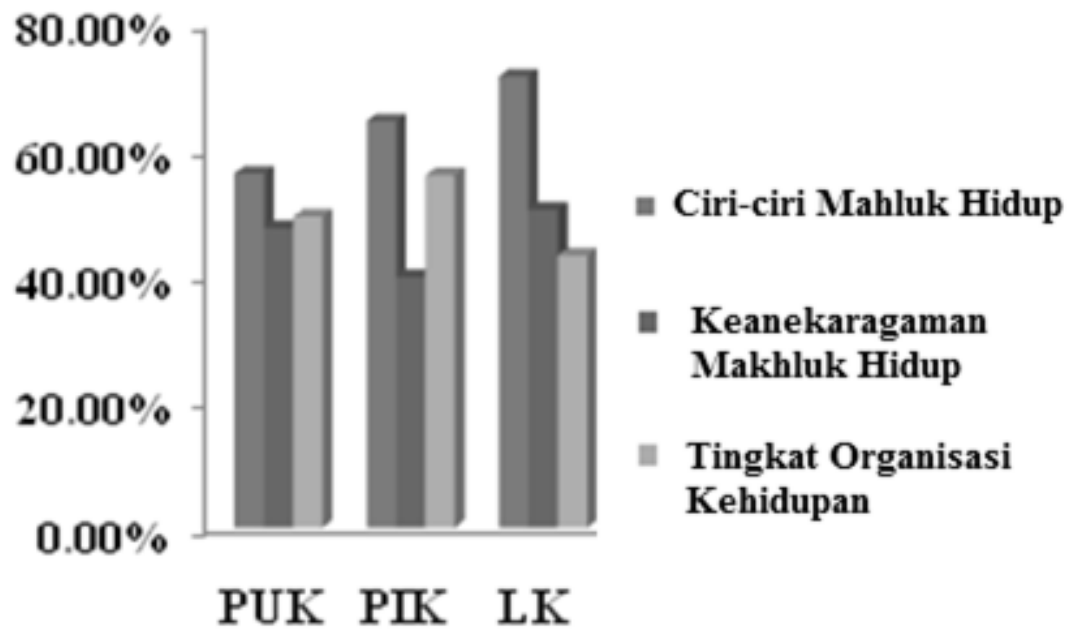

Gambar 2. Perbandingan Persentase Miskonsepsi pada Materi Ciri-Ciri Makhluk Hidup, Keanekaragaman Makhluk Hidup, dan Tingkat Organisasi Kehidupan.

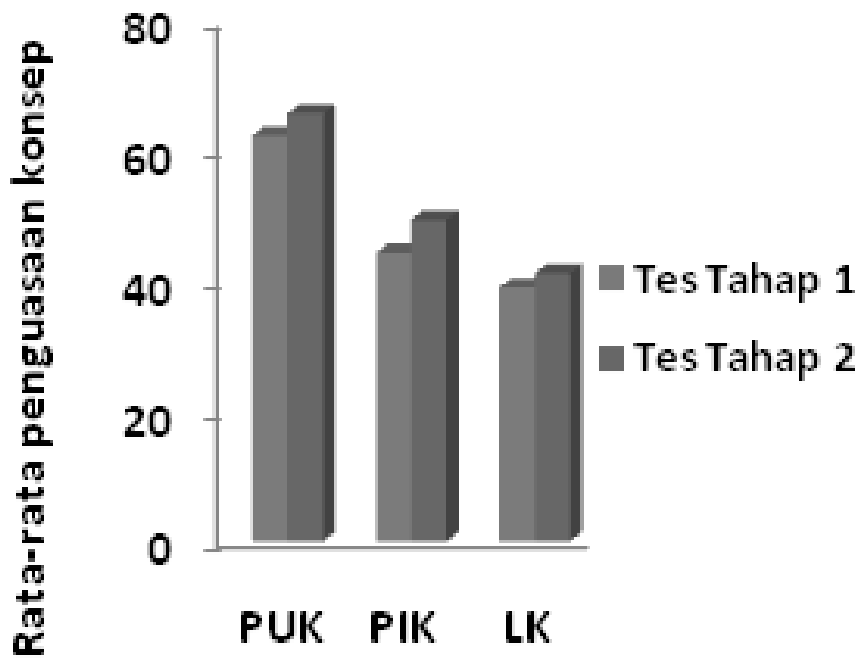

Gambar 3 Perbandingan Rata-Rata Penguasaan Konsep Siswa pada Tes Tahap 1 dan Tes Tahap 2 
Selain miskonsepsi, diperoleh persentase siswa yang menguasai konsep lebih rendah daripada siswa yang tidak tahu konsep. Berdasarkan data angket diagnostik kesulitan belajar, diketahui bahwa faktor penyebab kesulitan belajar biologi dari siswa pada ketiga kelompok sampel menunjukkan faktor penyebab yang berasal dari siswa dan guru tidak berpengaruh signifikan (sangat lemah), sedangkan faktor penyebab yang berasal dari sumber belajar baik berupa buku maupun media internet tergolong lemah. Meskipun tergolong lemah, faktor yang berasal dari sumber belajar memberi sedikit pengaruh terhadap penguasaan konsep siswa, dimana terdapat banyak istilah dalam bahasa latin yang sulit dipahami dan kurangnya minat siswa dalam membaca dan menelaah buku untuk dapat memahami konsep yang benar, serta kurangnya minat siswa maupun keterbatasan siswa dalam menggunakan media internet guna mengikuti perkembangan ilmu pengetahuan.

\section{Retensi Penguasaan Konsep}

Berdasarkan hasil retest, diperoleh retensi penguasaan konsep siswa selama dua minggu pada SMP di pusat kota meningkat sebesar $5,70 \%$, retensi penguasaan konsep siswa pada SMP di pinggiran kota meningkat sebesar $11,69 \%$, dan retensi penguasaan konsep siswa pada SMP di luar kota meningkat sebesar 5,75\%. Berikut adalah gambaran hasil tes penguasaan konsep pada tahap satu dan tahap dua.

Berdasarkan hasil uji t, terdapat perbedaan ratarata penguasaan konsep siswa antara tahap tes tahap satu dan tes tahap dua pada siswa SMP di pusat kota dan SMP di pinggiran kota, sedangkan pada siswa SMP di luar kota tidak terdapat perbedaan rata-rata penguasaan konsep siswa pada tes tahap satu dan tes tahap dua. Hal tersebut menunjukkan retensi penguasaan konsep siswa SMP di pusat kota dan SMP di pinggiran kota lebih baik daripada retensi siswa SMP di luar kota. Perbedaan retensi penguasaan konsep siswa pada ketiga kelompok sampel dapat dipengaruhi oleh faktor kelupaan pada siswa. Menurut Puspita [22], menyatakan bahwa informasi yang disimpan dalam memori dalam jangka panjang dapat berpindah ke memori jangka pendek sehingga kelupaan dapat terjadi. Hal tersebut merupakan faktor yang dapat mempengaruhi retensi (daya ingat) siswa. Berkaitan dengan hal tersebut. Menurut Crossgroven [23] dan Novak [24], jika retensi dapat ditingkatkan, maka dapat menghindari terjadinya miskonsepsi. Retensi dapat ditingkatkan dengan penggunaan strategi pembelajaran aktif dan pembelajaran bermakna dapat melibatkan siswa yang secara aktif dalam mencari hubungan antara pengetahuan yang ada sebelumnya dan pengetahuan baru.

\section{KESIMPULAN}

Berdasarkan hasil penelitian dan pembahasan, dapat diperoleh kesimpulan yaitu (1) Penguasaan konsep biologi pada siswa SMP di pusat kota tergolong dalam kategori tinggi, penguasaan konsep biologi pada siswa SMP di pinggiran kota, tergolong dalam kategori sedang, dan penguasaan konsep biologi pada siswa SMP di luar kota tergolong dalam kategori rendah. Hal ini dibuktikan dengan adanya perbedaan penguasaan konsep siswa SMP di pusat kota, SMP di pinggiran kota, dan SMP di luar kota; (2) Miskonsepsi pada materi ciri-ciri makhluk hidup, kenekaragaman makhluk hidup, dan tingkat organisasi kehidupan pada siswa SMP di pusat Kota, SMP di pinggiran kota, dan SMP di luar kota termasuk dalam kategori yang sama yaitu sedang. Hal ini dibuktikan dengan tidak adanya perbedaan miskonsepsi biologi pada siswa SMP siswa SMP di pusat kota, SMP di pinggiran kota, dan SMP di luar kota: (3) Miskonsepsi materi ciri-ciri makhluk hidup termasuk dalam kategori tinggi, miskonsepsi materi kenekaragaman makhluk hidup termasuk dalam kategori sedang dan miskonsepsi materi tingkat organisasi kehidupan termasuk dalam kategori sedang; (4) Retensi penguasaan konsep selama dua mingggu, pada siswa SMP di pusat kota meningkat sebesar $5,70 \%$, pada siswa pada SMP di pinggiran kota meningkat sebesar $11,69 \%$, dan pada siswa SMP di luar kota meningkat sebesar $5,75 \%$.

\section{Daftar Pustaka}

[1] BSNP. 2006. Standar Isi untuk Pendidikan Dasar dan Menengah. Jakarta. 2013. Daya Serap Ujian Nasional (Online): didownload pada Senin, 17 Juni 2013. Dari http://litbang.kemdikbud.go.id/index.php/bsnp

[2] Gonzales,P., Trevor W., Leslie J., Stephen R., David K., and Summer, B. 2009. Highlights from TIMSS 2007: Mathematics and Science Achievement of U.S. Fourth- and Eighth-Grade Students in an International Contex. Institute of Education Science.

[3] Nurjanah, S.I., Suwarto WA, dan Idam Ragil WA. 2012. Model Kooperatif Tipe TGT untuk Meningkatkan Pemahaman Konsep Koperasi pada Mata Pelajaran IPS. Jurnal FKIP PGSD: Hal 1-7.

[4] Nasution,R.2012. Persepsi Siswa tentang Kesulitan Belajar pada Materi Sistem Gerak Manusia di SMA Swasta Kecamatan Medan Tembung. Skripsi. Tidak Dipublikasikan. Universitas Medan.

[5] Ross, Keith. 2003. Alternative Framework and Miconceptions in Primary Science. Gordon Guest, UWE, Bristol.

[6] Soyibo,K. 1995. A Review of Some Sources of Students' Misconceptions in Biology. Singapore Journal of Education : Volume 15.

[7] Wilantara,I P.K. 2003. Implementasi Model pemebelajaran Konstruktivisme dalam Pembelajaran Fisika untuk Mengubah Miskonsepsi ditinjau dari Penalaran Formal Siswa. Tesis. Tidak dipublikasikan. Institut Keguruan dan Ilmu Pendidikan Singaraja. Singaraja.

[8] Suratno,T. 2007. Peranan Kontruktivisme dalam pembelajaran dan Pengajaran Sains.Makalah. 
Seminar Internasional Pendidikan IPA FITK UIN.

[9] Setyadi,E. 2012. Miskonsepsi Tentang Suhu dan Kalor Ppda Siswa Kelas 1 di SMA Muhammadiyah Purworejo, Jawa Tengah. Berkala Fisika Indonesia: Volume 4 Nomor 1.

[10] Carey, Susan. 1986. Cognitive Science and Science Education. American Psychologist: 41, Nomor 10,Hal.1123-1130.

[11] Hermawati,N.Y.M. 2012. Pengaruh Model Pembelajaran Inkuiri Terhadap Penguasaan Konsep Biologi Dan Sikap Ilmiah Siswa SMA Ditinjau Dari Minat Belajar Siswa. Program Pendidikan Sains Pascasarjana. Universitas Pendidikan Ganesha.

[12] Bandura,A. 1971. Social Learning Theory. New York: General Learning Press.

[13] Fardheen. 2013. Prinsip Retensi dan Transfer (Online): didonwload pada 11 Juni 2013 dari http://ourlz.blogspot.com/2013/05/jurnalprinsip-retensi-dan-transfer.html

[14] Shi,J., William B.W., Jennifer M.M.,Nancy A.G., Quentin V., and Jennifer K.K. 2010. A Diagnostic Assessment for Introductory Molecular and Cell Biology CBE-Life Sciences Education: Volume 9, Hal.453-461

[15] Hasan,B.,Bagayoko,D., and Kelley, E.L. 1999. Misssconceptions and the certainty of Response Index (CRI). Phys.Educ: Volume 34, Nomor 5.

[16] Hakim,A.,Liliasari, dan Kadarohman. 2012. Student Concept Undertanding of Natural Product Chemistry in Primary and Secondary Metabolites Using the Data Collecting Technique of Modified CRI. International Online Journal Of Educational Sience: Volume 4, Nomor 3,Hal. 544-553.

[17] Arikunto,S. .2009. Dasar-dasar Evaluasi Pendidikan. Jakarta:Rineka Cipta

[18] Hidayati,F. 2012. Kajian Kesulitan Belajar Siswa Kelas VII SMP Negeri 16 Yogyakarta dalam Mempelajari Aljabar. Skripsi. Tidak dipublikasikan. Universitas Yogyakarta.

[19] Sugiyono.2013. Metode Penelitian Kuantitatif Kualitatif dan R\&D. Bandung : Alfabeta.

[20] Nur, A.S. 2013. Peran konsep diri dan minat belajar biologi terhadap penguasaan konsep biologi dengan efikasi diri sebagai variabel mediator pada siswa sma. Jurnal Psikologi Terapan dan Pendidikan: Volume 1. Nomor 1. Universitas Ahmad Dahlan. Yogyakarta.

[21] Ma'rifah,M., Sumarni W., dan Kusoro S. 2012. Keefektifan Pereduksian Miskonsepsi Melalui Strategi Konflik Kognitif Pada Pemahaman Konseptual dan Algoritmik. Chemistry In Education: Volume 1. Nomor 2. Hal. 43.

[22] Puspita,I.D. 2012. Retensi Pengetahuan, Sikap, dan Prilaku Pasca Pelatihan Gizi Seimbang pada Siswa Kelas 5 dan 6 di 10 Sekolah Dasar
Terpilih Kota Depok. Skripsi. Tidak Dipublikasikan. Universitas Indonesia.

[23] Crossgrove,K., and Kristen L.Curan. 2007. Using Clickers in Nonmajors- and Majors-Level Biology Courses: Student Opinion, Learning, and Long-Term Retention of Course Material. CBE-Life Sciences Education: Volume. 7, Hal.146-154.

[24] Novak,J.D. 2003. The Promise of New Ideas and New Technology for Improving Teaching and Learning. Cell Biology Education: Volume 2, Hal.122-132. 